Referências

1. Souza LD, Silva RA, Jansen K, Kuhn RP, Horta BL, Pinheiro RT. Suicidal ideation in adolescents aged 11 to 15 years: prevalence and associated factors. Rev Bras Psiquiatr. 2010;32(1):37-41.

2. Miguel EC, Mercadante MT, Grisi S, Rohde LA. The national science and technology institute in child and adolescence developmental psychiatry: a new paradigm for Brazilian psychiatry focused on our children and their future. Rev Bras Psiquiatr. 2009;31(2):85-8.
3. Couto MC, Duarte CS, Delgado PG. Child mental health and Public Health in Brazil: current situation and challenges. Rev Bras Psiquiatr. 2008;30(4):390-8.

4. Moraes C, Abujadi C, Ciasca SM, Moura-Ribeiro MV. Brazilian child and adolescent psychiatrists task force. Rev Bras Psiquiatr. 2008;30(3):294-5.

5. Roesler J, Petcoff M, Azam A, Westberg S, Kinde M, Crosby A. Nonfatal suicide attempts and other self-inflicted harm. Beltrami County youths, 20022006. Minn Med. 2009;92(8):53-5.

\section{Brain-derived neurotrophic factor and suicidal behavior in patients with posttraumatic stress disorder}

\section{Fator neurotrófico derivado do encéfalo e comportamento suicida em pacientes com transtorno de estresse pós- traumático}

Posttraumatic stress disorder (PTSD) is a severe illness affecting a substantial part of the population in both Western and developing countries. Many individuals suffering from PTSD display suicidal behavior. The association between PTSD and suicidal behavior has been observed both in clinical and in general population samples and is irrespective of the type of trauma that led to PTSD. The neurobiology of suicidal behavior in individuals of PTSD is not clear and is subject of research. ${ }^{1}$ Brain-derived neurotrophic factor (BDNF) may be involved in the neurobiology of suicidal behavior in PTSD because of its potential role in the pathophysiology of stress-related disorders.

BDNF is one of mammalian neurotrophins which are homodimeric proteins. Mammalian neurotrophins also include nerve growth factor, neurotrophin (NT) 3 and NT 4/5. BDNF is involved in neuronal growth, phenotypic maturation, morphological plasticity, and synthesis of proteins for differentiated functioning of neurons and synaptic functioning.

Multiple lines of evidence suggest that BDNF function is dysregulated in PTSD. ${ }^{2-4}$ A recent study has demonstrated significantly lower plasma BDNF levels in PTSD patients compared to healthy control subjects. ${ }^{2}$ Stressors regulate the expression of BDNF. It has been demonstrated that animals showing ongoing behavioral disturbances after stress showed BDNF downregulation and neurotrophic tyrosine kinase receptor, type 2 (TrkB) upregulation in a subregion of the hippocampus, compared with controls. ${ }^{3}$ Chronic stress or prolonged exposure to glucocorticoids decrease BDNF levels and damage hippocampal functioning, by producing dendritic retraction, restructuring, and disconnection. ${ }^{4}$
Postmortem brain studies in suicidal subjects with or without depression, studies of levels of BDNF in blood cells/plasma of suicidal patients, and genetic association studies linking BDNF to suicide suggest that suicidal behavior may be associated with a decrease in BDNF functioning. 5 A postmortem study found that mRNA level of BDNF was significantly reduced, independently and as a ratio to neuron-specific enolase, in both the prefrontal cortex and hippocampus of suicide subjects compared with nonpsychiatric healthy control subjects. ${ }^{5}$ Interestingly, the decrease in expression of BDNF was present in all suicide subjects regardless of psychiatric diagnosis.

It is not clear whether abnormal BDNF function is a marker of PTSD itself, or a marker of a neural vulnerability to PTSD. It is reasonable to hypothesize that reduced BDNF function increases vulnerability to PTSD and traumatic stress further decreases BDNF function. If BDNF dysregulation contributes to the pathophysiology of PTSD and suicidal behavior, it may underlie both conditions. If BDNF dysregulation is mostly a result of traumatic stress, it is logical to suggest that BDNF abnormalities mediate the effect of PTSD on suicidal behavior. Future studies of the role of BDNF function in the neurobiology of PTSD and suicidal behavior may lead to the development of new treatment modalities. It is interesting to hypothesize that treatment-induced enhancements of BDNF can facilitate neural integrity and recovery of function in PTSD, and consequently prevent suicidal behavior. This may be an important step in the direction of preventing suicide in individuals with PTSD.

Leo Sher

James J. Peters Veterans' Administration Medical Center and Mount Sinai School of Medicine, New York, USA 


\section{Disclosures}

\begin{tabular}{|c|c|c|c|c|c|c|c|}
\hline $\begin{array}{c}\text { Writing group } \\
\text { member }\end{array}$ & Employment & $\begin{array}{l}\text { Research } \\
\text { grant }{ }^{1}\end{array}$ & $\begin{array}{l}\text { Other research grant or } \\
\text { medical continuous } \\
\text { education }\end{array}$ & $\begin{array}{l}\text { Speaker's } \\
\text { honoraria }\end{array}$ & $\begin{array}{c}\text { Ownership } \\
\text { interest }\end{array}$ & $\begin{array}{c}\text { Consultant/ } \\
\text { Advisory board }\end{array}$ & Other ${ }^{3}$ \\
\hline Leo Sher & - & - & - & - & - & - & - \\
\hline
\end{tabular}

References

1. Sher L. Neurobiology of suicidal behavior in posttraumatic stress disorder. Expert Rev Neurother. 2010;10(8):1233-5.

2. Dell'osso L, Carmassi C, Del Debbio A, Dell'osso MC, Bianchi C, da Pozzo E, Origlia N, Domenici L, Massimetti G, Marazziti D, Piccinni A. Brain-derived neurotrophic factor plasma levels in patients suffering from post-traumatic stress disorder. Prog Neuropsychopharmacol Biol Psychiatry. 2009;33(5):899-902.
3. Kozlovsky N, Matar MA, Kaplan Z, Kotler M, Zohar J, Cohen H. Longterm down-regulation of BDNF mRNA in rat hippocampal CA1 subregioncorrelates with PTSD-like behavioral stress response. Int J Neuropsychopharmacol. 2007;10(6):741-58.

4. Lee BH, Kim YK. The roles of BDNF in the pathophysiology of major depression and in antidepressant treatment. Psychiatry Investig. 2010;7(4):231-5.

5. Dwivedi Y. Brain-derived neurotrophic factor: role in depression and suicide. Neuropsychiatr Dis Treat. 2009;5:433-49. 